\title{
Flexible Amide-Bonded Zn(II) Porphyrin Dimer: Electronic Structure Investigation and Its Induced Chirality
}

\author{
Mingfeng Qin, ${ }^{a}$ Minzhi Li, ${ }^{a}$ Weihua Zhu, ${ }^{a}{ }^{@ 1} \mathrm{Li} \mathrm{Xu}_{1}{ }^{\mathrm{a}}$ and Xu Lianga ${ }^{\mathrm{a}, \mathrm{b} 2}$ \\ a School of Chemistry and Chemical Engineering, Jiangsu University, Zhenjiang 212013, P. R. China \\ ${ }^{\mathrm{b}}$ State Key Laboratory of Coordination Chemistry, Nanjing University, Nanjing 210000, P. R. China \\ ${ }^{\circledR 1}$ Corresponding authorE-mail: sayman@ujs.edu.cn \\ ${ }^{\circledR 2}$ Corresponding authorE-mail: liangxu@ujs.edu.cn
}

\begin{abstract}
In this paper, an in-depth electronic structure study of a xanthene-bridged and amide-bonded Zinc(II) porphyrin dimer ( $\mathrm{Zn}^{I I}$ dimer) by solvent/anion dependent spectroscopy, electrochemistry and spectroelectrochemistry has been described. In addition, the self-assembly behaviors between this $Z n^{I I}$ dimer and chiral (1S,2S)-(+)- and (1R,2R)-(-)-1,2diaminocyclohexane exhibited distinctive derivative-shaped band morphology of the pseudo-Faraday- $A_{1}$ terms on the MCD spectra, and the molecular polarization could be modulated by the chirality of guest chiral diamines.
\end{abstract}

Keywords: Porphyrin dimer, spectroscopy, electrochemistry, spectroelectrochemistry, influenced chirality.

\section{Подвижный амидосвязанный димер Zn(II)-порфирина: исслеАование электронной структуры и инАуцированная хиральность}

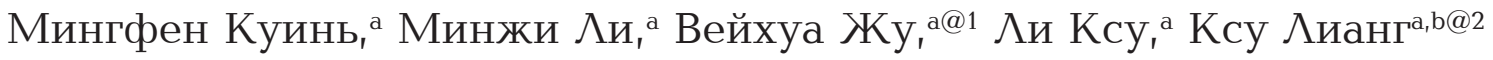

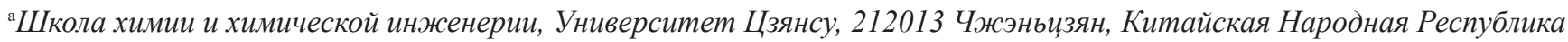 \\ 'Государственная лаборатория координационной химии, Университет Нанкин, 210000 Нанкин, Китайская \\ Народная Республика \\ @1E-mail: sayman@ujs.edu.cn \\ @2E-mail: liangxu@ujs.edu.cn
}

\begin{abstract}
В работе изучена электронная структура димера изинкового комплекса порфирина (Zn димер), связанного через ксантеновый мостик и амидную группу, с использованием растворитель/анион зависимой спектроскопии, электрохимии и спектроэлектрохимии. Характер самосборки между $Z n^{I I}$ димером и хиральным $(1 S, 2 S)-(+)-$ u (1R,2R)-(-)-1,2-диаминоциклогексаном проявляется в спектрах магнитного кругового дихроизма в виде четкой полосы, соответствующей псевдо-Фарадеевскому $A_{1}$-терму, а молекулярная поляризация зависит от гостевых хиральных диаминов.
\end{abstract}

Ключевые слова: Порфирин, димер, спектроскопия, электрохимия, спектроэлектрохимия, индуцированная хиральность. 


\section{Introduction}

Porphyrin oligomers containing two or more covalently linked macrocyclic rings have received considerable attention in recent years due to their unique electronic structures and optical properties, ${ }^{[1]}$ such as doubly- or triply-fused co-planar porphyrins, ${ }^{[2]}$ alkyne-bridged porphyrin $\operatorname{strands}^{[3]}$ and $\pi$-phenylene-bridged twisted/ planar porphyrin dimers. ${ }^{[4]}$ From this point of view, there has been considerable research interests in the synthesis and properties of cofacial porphyrin dimers, ${ }^{[5]}$ since these compounds provide a possible pathway for mimicking the electron transfer properties of the bacteriochlorophyll dimer in photosystem II, which is often referred as the "special pair" ${ }^{[6]}$ On the other hand, supramolecular chirality is a growing multidisciplinary field of modern research and attracts much strong attention from the scientific community because of its vital importance for various natural processes and for its attractive possibilities for new smart technologies. ${ }^{[7]}$ Of the vast number of host-guest and self-associated systems, supramolecular assemblies based on porphyrin chromophores are of particular interest for in depth investigation and potential application as a consequence of them having specific and well-suited physicochemical and spectroscopic properties. ${ }^{[8]}$ In this paper, the study on the solvent-dependent spectroscopic, electrochemical and spectroelectrochemical properties will be carried out. Also, the electronic structure study of its induced chirality upon addition of (1S,2S)$(+)-$ and (1R,2R)-(-)-1,2-diaminocyclohexane will be illustrated, since its unique property of producing a stable 1:1 tweezer complex exclusively without any further equilibrium steps as a consequence of its remarkably large association constant.

\section{Experimental}

\section{Materials and Instruments}

All reagents and solvents were of commercial grade and were used without further purification except where noted, and ACS spectral pure grade solvents were used for spectroscopic, electrochemical and spectroelectrochemical measurements. The $\mathrm{Zn}^{\text {II }}$ porphyrin dimer $\mathbf{1}$ (Scheme 1) was synthesized according to the literature. ${ }^{[9]}$ Cyclic voltammetry was performed in a three-electrode cell using a Chi-730D electrochemistry station. A glassy carbon disk electrode was utilized as the working electrode while a platinum wire and a saturated calomel electrode (SCE) were employed as the counter and reference electrodes, respectively. UV-visible spectroelectrochemical measurements were performed with a home-made optically transparent thinlayer cell with Pt mesh as the working electrode. The potential was applied using a Chi-730D electrochemistry station. UV-visible spectra were recorded with a HP 8453A diode array spectrophotometer. All electrochemical and spectroelectrochemical measurements were carried out under a nitrogen atmosphere. Magnetic circular dichroism (MCD) spectra were recorded on a JASCO J-815 spectrodichrometer equipped with a JASCO permanent magnet, which produces magnetic fields of up to $1.6 \mathrm{~T}$ (1 $\mathrm{T}=1.0$ tesla) with both parallel and antiparallel fields.

\section{Results and Discussion}

\section{Optical Spectroscopy and Induced Chirality}

To comprehensively understand the effect of the presence or absence of the (1R,2R)-(-)-1,2-diaminocyclohexane guest molecule on the electronic structure of $\mathbf{1}$ and its optical activity, the magnetic circular dichroism (MCD), circular dichroism (CD) and electronic absorption spectra measurement were carried out (Figure 1). It should be noted that $\mathrm{CD}$ and MCD analyses are mutually complementary in aiding the interpretation of the excited states, especially in the case of chiral bis- (or multi-) porphyrin systems; CD spectroscopy is sensitive to interchromophoric throughspace coupling (exciton coupling), whereas MCD spectroscopy is sensitive to intrachromophoric coupling (coupling occurring between electronic transitions within the same chromophoric unit). Since the optical spectroscopy is one of the most useful approaches for characterizing porphyrins and their analogs, due to the presence of the forbidden and allowed Q- and B-bands of Gouterman's 4-orbital mod$\mathrm{e}^{[10]}$ in the 500-600 and 400-450 nm regions, respectively. The four spin-allowed $\mathrm{M}_{\mathrm{L}}= \pm 4 \rightarrow \pm 5$ excitations result in two orbitally degenerate ${ }^{1} \mathrm{E}_{u}$ excited states, due to the $\Delta \mathrm{M}_{\mathrm{L}}= \pm 9$, and $\Delta \mathrm{M}_{\mathrm{L}}= \pm 1$ transitions. This results in the forbidden and allowed Q- and B-bands of Gouterman's 4-orbital model and Michl's perimeter model ${ }^{[11]}$ for porphyrins, since an incident photon can provide only one quantum of orbital angular momentum. In the MCD spectra, the main electronic $\mathrm{Q}(0,0)$ and $\mathrm{B}(0,0)$ bands can be readily identifed due to the presence of intense derivative-shaped Faraday- $A_{1}$ terms. In the context of lower symmetry compounds, these are replaced by coupled pairs of oppositely-signed Gaussian-shaped Faraday- $B_{0}$ terms. ${ }^{[12]}$ The major UV-visible absorption bands of $\mathbf{1}$ in $\mathrm{CH}_{2} \mathrm{Cl}_{2}$ are similar with the monomeric $\mathrm{Zn}^{\mathrm{II}}$-mesotetraphenylporphyrin. The B- (or Soret) band lies at $412 \mathrm{~nm}$, and $\mathrm{Q}(0,1)$ and $\mathrm{Q}(0,0)$ bands observed at 550 and $594 \mathrm{~nm}$.

Upon addition of 1.0 eq of (1R,2R)-(+)-1,2-diaminocyclohexane, there is a slight red-shift of the B-band to $414 \mathrm{~nm}$, and a clear red-shift of the $\mathrm{Q}(0,1)$ and $\mathrm{Q}(0,0)$ bands to 556 and $602 \mathrm{~nm}$ is observed at the same time. The MCD spectra of $\mathrm{Zn}^{\mathrm{II}}$ dimer $\mathbf{1}$ in the presence and absence of 1.0 eq. of $(1 \mathrm{R}, 2 \mathrm{R})-(+)-1,2$-diaminocyclohexane are all similar with the monomeric ZnTPP, since the relative energies of the frontier $\pi$-MOs are very similar with each other. Derivative-shaped positive pseudo- $A_{1}$ terms are observed in the MCD spectra of $\mathbf{1}$ for the both Q- and B-band region. It is noteworthy that the B-band signals are signifcantly less symmetrical than those typically observed for $\mathrm{Zn}^{\text {II }}$ tetraphenylporphyrins and the $\mathrm{Zn}^{\mathrm{II}}$ dimer containing archiral guest molecule, such as DABCO. Importantly, the electronic transitions of different polarizations generally exhibit MCD signals of opposite sign and it was found that the two high energy transitions of the same positive CD sign are indeed of different polarization, at 437 and $425 \mathrm{~nm}$ with negative to positive sequence. On the other hand, the observed CD signal also indicates the two porphyrin rings were arranged in a clock-wise manner modulated by guest $(1 \mathrm{R}, 2 \mathrm{R})-(-)$ -1,2-diaminocyclohexane molecule. When (1S,2S)-(+)-1,2diaminocyclohexane was used, no changes were observed 
in both UV-vis and MCD spectra, too. Also, the opposite sign of CD signals were observed upon addition of (1S,2S)(+)- and (1R,2R)-(-)-diaminocyclohexane to $\mathbf{1}$ in $\mathrm{CH}_{2} \mathrm{Cl}_{2}$, and significant difference of the $\mathrm{CD}$ intensity could be explained as the modulation of molecular polarization through self-assembly by guest chiral diamines.

\section{Solvent and Anion-Dependent Electrochemistry}

To gain further insight into the electronic structures of $\mathrm{Zn}^{\mathrm{II}}$ dimer and the effect of solvent polarity on the electronic properties, reductive electrochemical measurements were carried out in $o$-dichlorobenzene $(o$-DCB) as a typical low-polar solvent, and high-polar dimethylformamide (DMF) and $\mathrm{PhCN}$ containing $0.1 \mathrm{M}$ various supporting electrolyte $\left[\mathrm{NBu}_{4}\right]^{+}\left[\mathrm{ClO}_{4}\right]^{-}(\mathrm{TBAP}),\left[\mathrm{NBu}_{4}\right]^{+}[\mathrm{Cl}]^{-}$ $(\mathrm{TBACl}), \quad\left[\mathrm{NBu}_{4}\right]^{+}[\mathrm{Br}]^{-}(\mathrm{TBABr}), \quad\left[\mathrm{NBu}_{4}\right]^{+}[\mathrm{F}]^{-} \quad(\mathrm{TBAF})$ and $\left[\mathrm{NBu}_{4}\right]^{+}[\mathrm{OAc}]^{-}(\mathrm{TBAOAc})$. The redox potentials $\left(E_{1 / 2}\right)$ values derived from both $\mathrm{CV}$ and DPV measurements (Figure 2). Thus, the influence of solvent polarity and anions of supporting electrolyte could be well illustrated. In DMF, $\mathrm{Zn}^{\mathrm{II}}$ dimer 1 reveals two reversible processes and one quasireversible processes in the reduction part at $E_{1 / 2}=-0.99,-1.39$ and $-1.79 \mathrm{~V}$, and one quasi-reversible process in the oxidation part at $E_{1 / 2}=1.13$ was also formed when TBAP was used as the supporting electrolyte. In should be mentioned that all reduction values are positively shifted in high-polar solvent DMF compared with the same compound in low-polar $o$-DCB solution containing $0.1 \mathrm{M}$ TBAP. Three reductions appeared at $E_{1 / 2}=-0.99,-1.39$ and -1.79 at the reduction part, and at $E_{1 / 2}=1.13$ for its oxidation in DMF. In addition, all electrochemical redox behaviors are similar with the monomeric $\mathrm{Zn}^{\mathrm{II}}$-tetraphenylporphyrin. ${ }^{[13]}$

The potentials and reversibility for the electrochemical reductions of $\mathrm{Zn}^{\mathrm{II}}$ dimer $\mathbf{1}$ depend markedly upon the anions in both high polar DMF and low polar $o$-DCB solutions, and this can be accounted for by differences in the interaction to different anions from supporting electrolyte (Figure 3). In $o$-DCB, the positive shift of the two reversible reduction processes were observed in the case of TBAB; TBAC and TBAF were used as the supporting electrolyte compared with TBAP, and the largest shift was observed

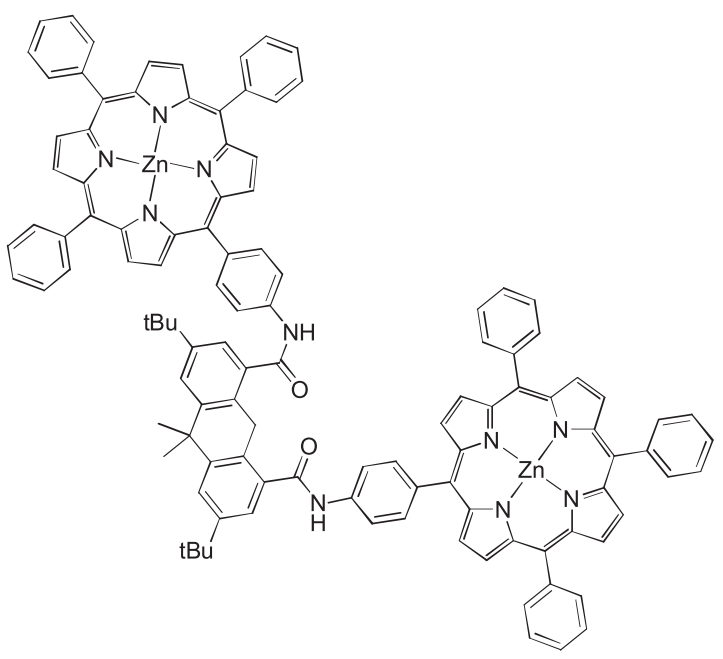

Scheme 1. Molecular structure of $\mathrm{Zn}^{\mathrm{II}}$ porphyrin dimer $\mathbf{1}$.
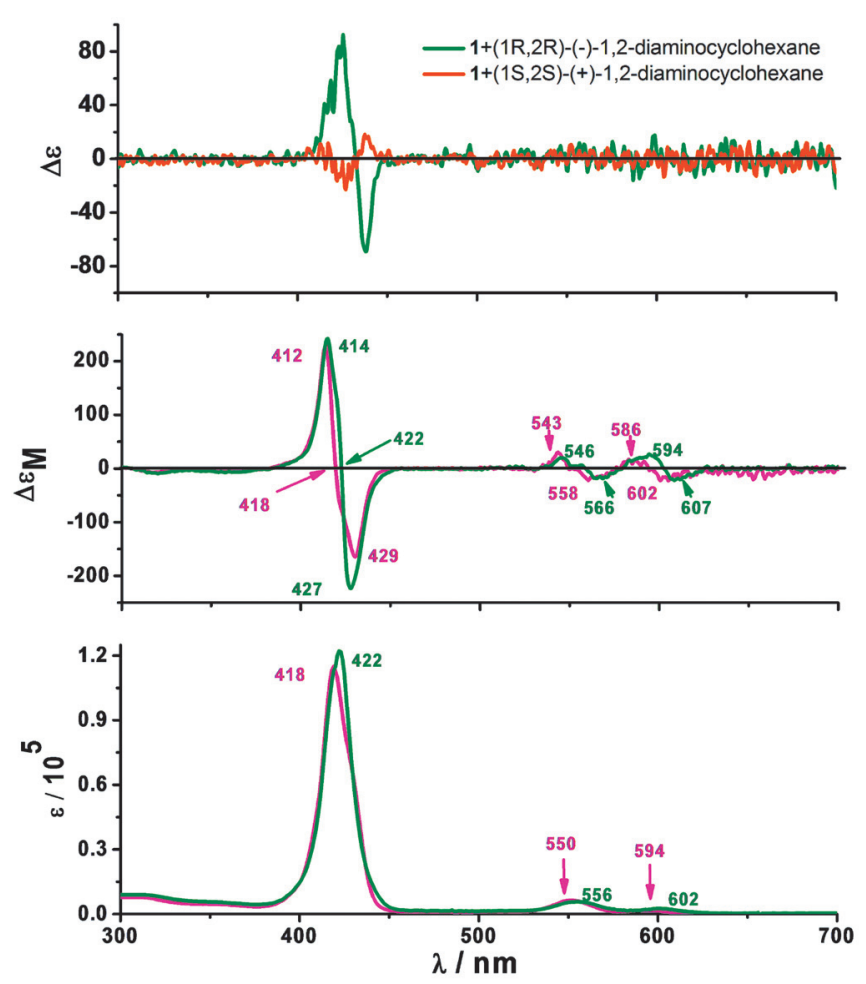

Figure 1. Circular dichroism (CD, up), magnetic circular dichroism (MCD, up) and UV-vis (bottom) spectra of $\mathbf{1}$ in the presence (red) and absence (green) of 1,2-diaminocyclohexane in $\mathrm{CH}_{2} \mathrm{Cl}_{2}$ at room temperature.

when TBAF was using. It should be pointed out that the flexible porphyrin dimers described in this study have almost same potential values with metallo-porphyrin monomer at their $1^{\text {st }}$ oxidation and reduction under same organic solution, probably due to the weak $\pi-\pi$ interaction between different porphyrin core. The slight change of higher energy region can be explained as the lower molecular symmetry arsing from the amide-bonded xanthene bridged porphyrin dimers' molecular structure.

\section{Solvent and Anion-Dependent Spectroelectrochemistry}

The first reduction step of $\mathbf{1}$ can be assigned to the reduction of porphyrin ring $\left[\mathrm{Zn}^{\mathrm{II}} \mathrm{Por}\right] /\left[\mathrm{Zn}{ }^{\mathrm{II}}\right.$ Por $]$ - process in both low polar $o$-DCB $\left(E_{\text {app }}=-1.42 \mathrm{~V}\right)$ and high polar DMF $\left(E_{\text {app }}=1.38 \mathrm{~V}\right)$ solvents, due to the almost identical spectral changes that are observed by thin-layer spectroelectrochemistry (Figure 4). The B-band of the $\mathrm{Zn}^{\text {II }}$ porphyrin dimer lies at $421 \mathrm{~nm}$ in $o$-DCB and $423 \mathrm{~nm}$ in DMF, which is shifted significantly to the red compared to the spectra that have been reported for $\mathrm{Zn}^{\mathrm{II}}$ porphyrin monomers at ca. $436 \mathrm{~nm}$ in similar solvents. ${ }^{[13]}$ Solvent polarity appears to have a significant effect on the spectral changes of doubly reduced $\mathrm{Zn}^{\text {II }}$ Por dimer 1 . Controlled potential reduction at $E=-1.82 \mathrm{~V}$ in DMF results in a significantly split B-bands at 436 and $476 \mathrm{~nm}$, while in $o$-DCB a single B-band is observed at $437 \mathrm{~nm}$ when a controlled potential value of $E=-1.72 \mathrm{~V}$ is applied. The spectral changes observed upon the first controlled potential oxidation, at $E=0.92 \mathrm{~V}$, indicate that the Soret band dramatically decreases and broadens in the same 

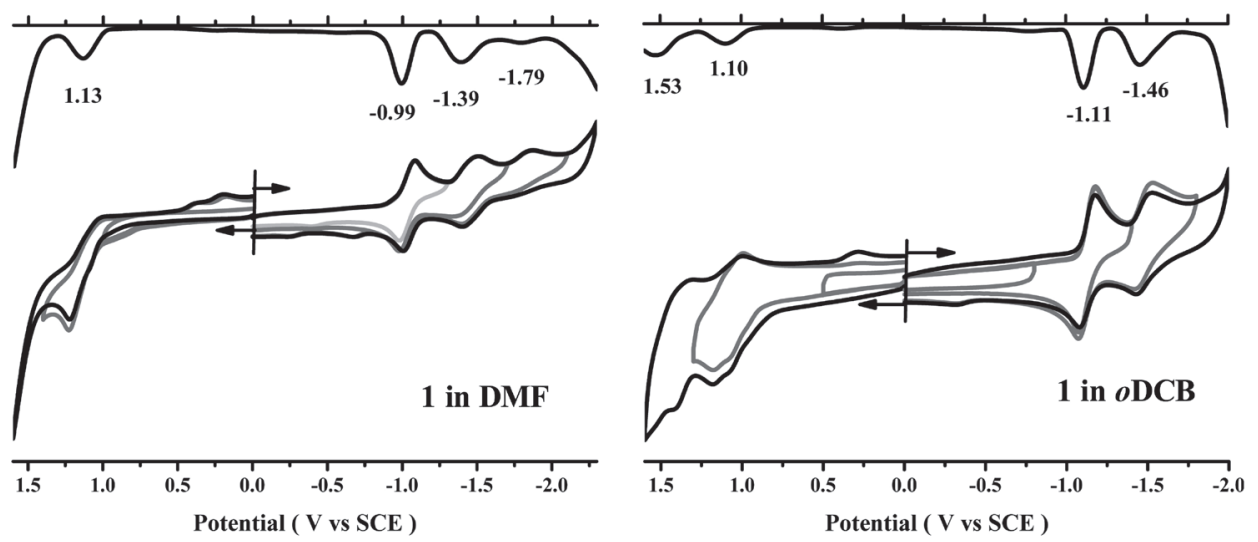

Figure 2. CV and DPV measurements of 1 in low polar solvent $o$-DCB and high polar DMF containing $0.1 \mathrm{M}$ TBAP, scan rate $100 \mathrm{mV} / \mathrm{s}$.
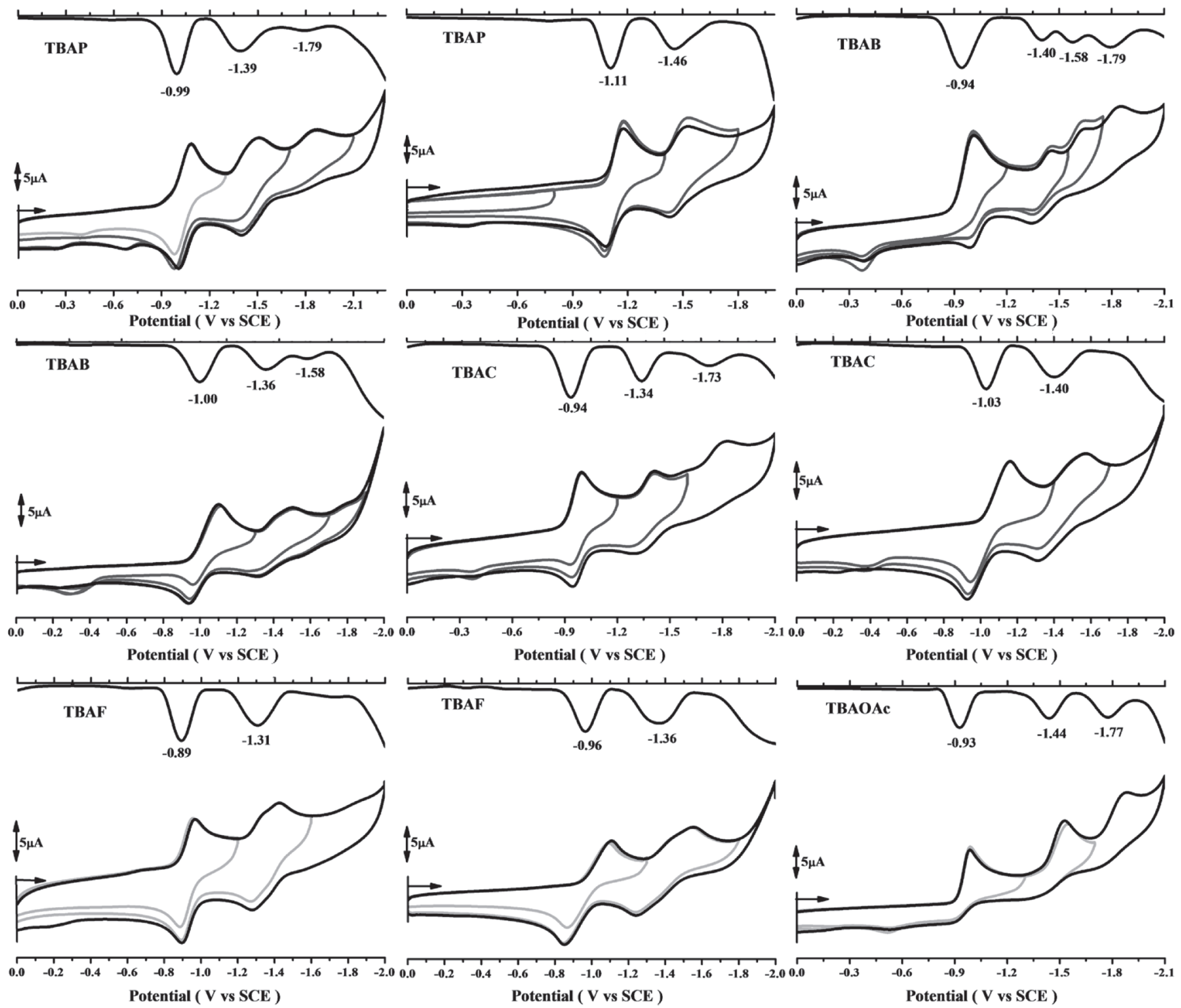

Figure 3. Reductive CV and DPV measurements of $\mathrm{Zn}^{\mathrm{II}}$ dimer 1 in $o$-DCB (left) and DMF (right) containing $0.1 \mathrm{M}^{2}\left[\mathrm{NBu}_{4}\right]^{+}\left[\mathrm{ClO}_{4}\right]^{-}$ (TBAP), $\left[\mathrm{NBu}_{4}\right]^{+} \mathrm{Br}(\mathrm{TBAB}),\left[\mathrm{NBu}_{4}\right]^{+} \mathrm{Cl}^{-}(\mathrm{TBAC}),\left[\mathrm{NBu}_{4}\right]^{+} \mathrm{Br}(\mathrm{TBAF})$ and $\left[\mathrm{NBu}_{4}\right]^{+} \mathrm{OAc}(\mathrm{TBAOAc})$. 
in DMF
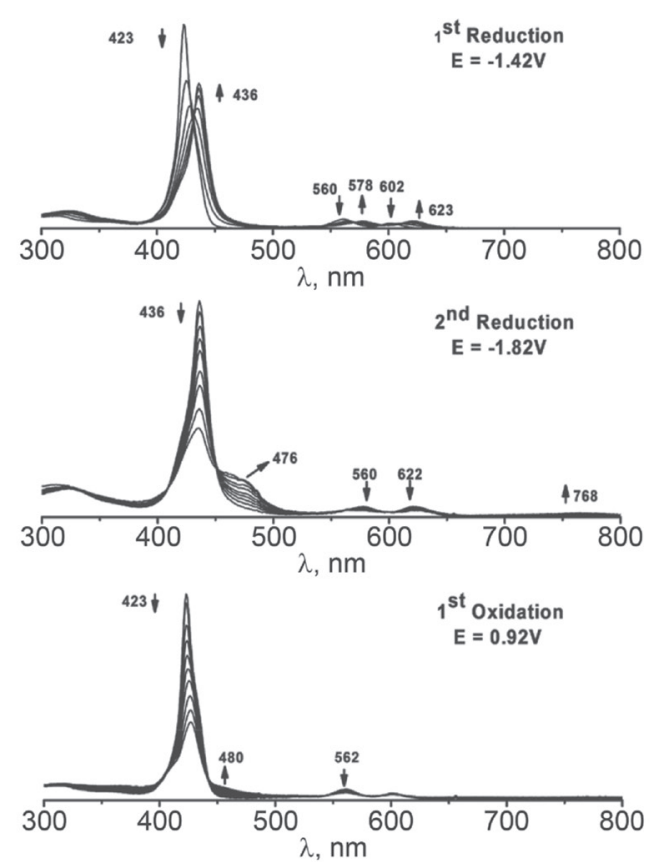

in 0 -DCB
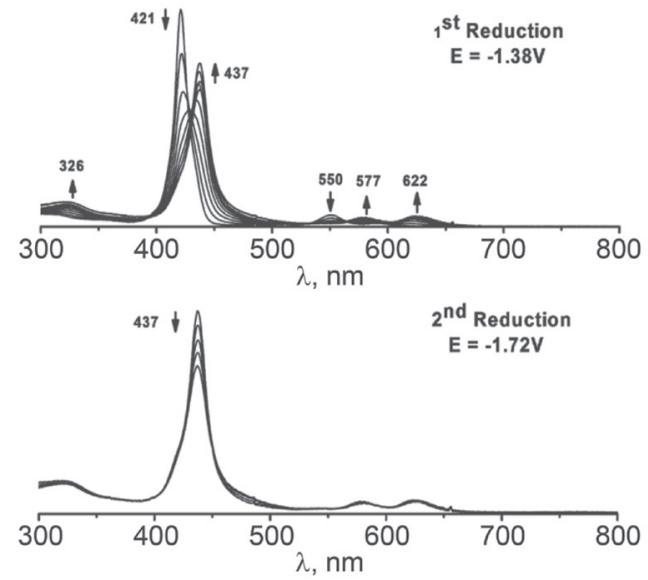

Figure 4. Spectral changes in the thin-layer UV-visible spectra of $\mathrm{Zn}^{\mathrm{II}}$ dimer complex 1 in DMF (left) and $o$-DCB (right) containing $0.1 \mathrm{M}$ TBAP.

TBAB

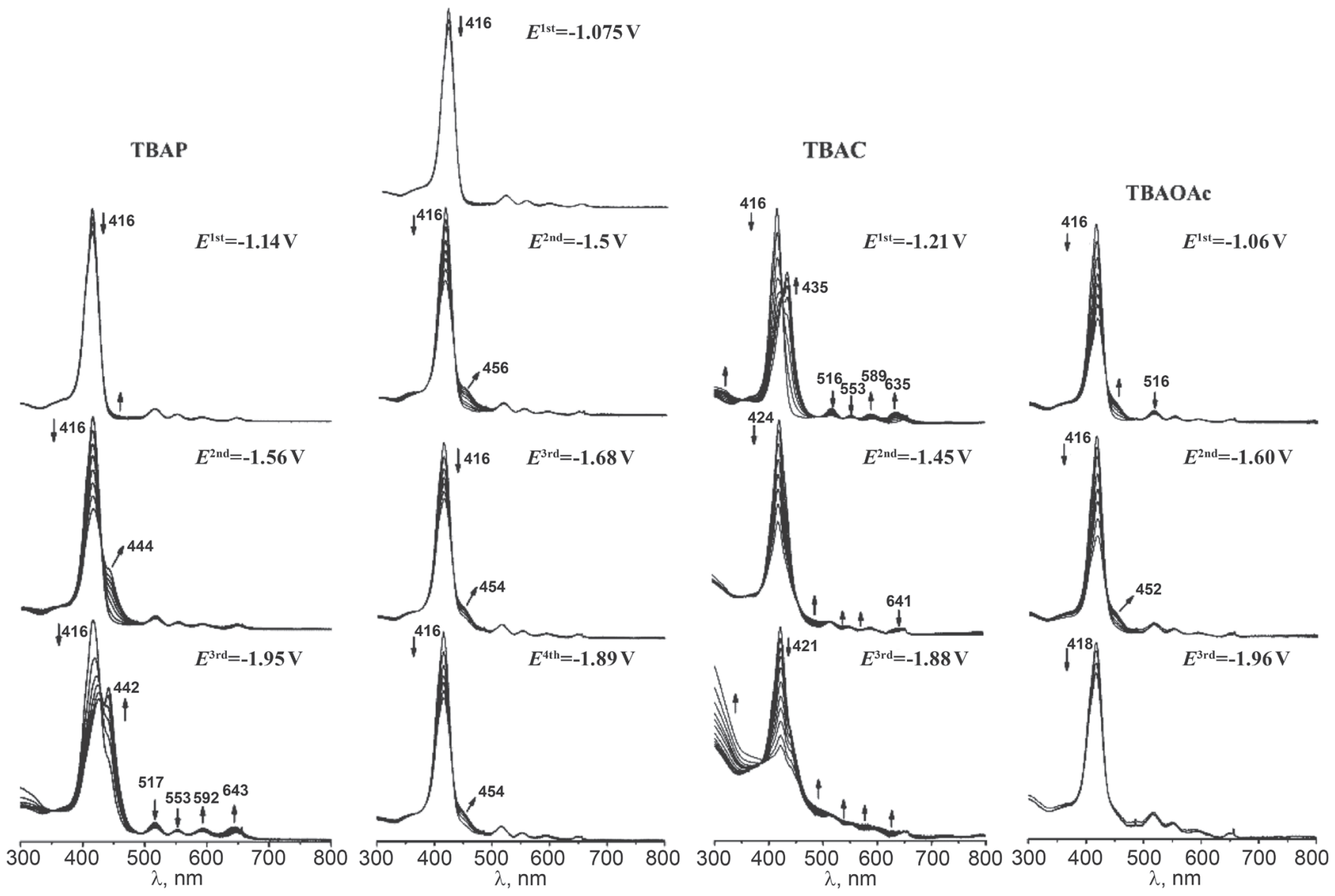

Figure 5. Spectral changes in the thin-layer UV-visible spectra of $\mathrm{Zn}^{\mathrm{II}}$ dimer complex 1 in DMF containing $0.1 \mathrm{M}^{2}\left[\mathrm{NBu}_{4}\right]^{+}\left[\mathrm{ClO}_{4}\right]^{-}\left(\mathrm{TBAP}^{2}\right.$, $\left[\mathrm{NBu}_{4}\right]^{+} \mathrm{Br}(\mathrm{TBAB}),\left[\mathrm{NBu}_{4}\right]^{+} \mathrm{Cl}^{-}(\mathrm{TBAC})$ and $\left[\mathrm{NBu}_{4}\right]^{+} \mathrm{OAc}-(\mathrm{TBAOAc})$. 
TBAP

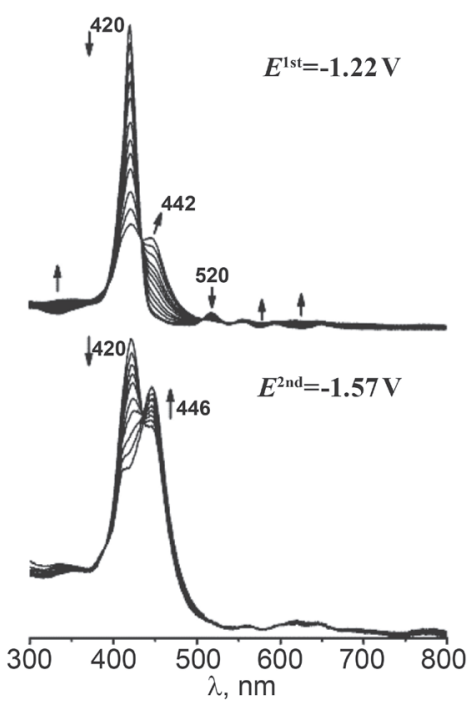

TBAC

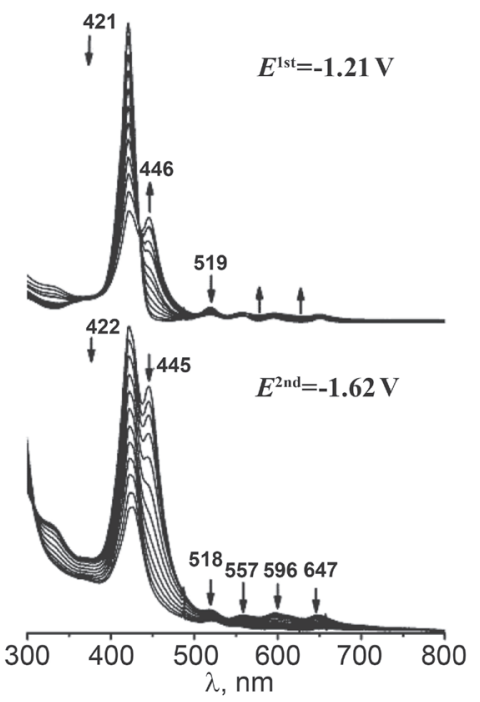

Figure 6. Spectral changes in the thin-layer UV-visible spectra of $\mathrm{Zn}^{\mathrm{II}}$ dimer complex $\mathbf{1}$ in $o$-DCB containing $\left.0.1 \mathrm{M}^{-\mathrm{NBu}}\right]_{4}^{+}\left[\mathrm{ClO}_{4}\right]^{]}$ (TBAP), $\left[\mathrm{NBu}_{4}\right]^{+} \mathrm{Br}^{-}(\mathrm{TBAB})$ and $\left[\mathrm{NBu}_{4}\right]^{+} \mathrm{Cl}^{-}(\mathrm{TBAC})$.

time. No visible band is seen in the spectrum of the doubly oxidized species in $\mathrm{Zn}{ }^{\mathrm{II}}$ Por dimer 1 in DMF. Contrary to what was observed during the first oxidation, the UV-visible spectral modifications are not reversible, and the spectrum of the singly oxidized form can't be recovered when the potential is set back to $E=+0.7 \mathrm{~V}$ or even lower potential. On the other hand, no spectral changes observed during the oxidation of $\mathrm{Zn}^{\text {II }}$ Por dimer $\mathbf{1}$ in low polar solvent $o$-DCB. The effect of the counter anion of the supporting electrolyte on the reductive spectroelectrochemical behavior of $\mathbf{1}$ has also been examined (Figures 5, 6), and was found to have a significant effect on the potentials and reversibility of the electroreductions in both DMF and $o$-DCB.

\section{Conclusions}

In summary, an in-depth study of the electronic structure of a synthetic xanthene-bridged and amide-bonded $\mathrm{Zn}^{\mathrm{II}}$ porphyrin dimer has been carried out, and the solvent/ anion dependent optical and redox properties have been analyzed and have been found to be broadly similar to those of the corresponding monomer complexes. In addtion, the observed electrochemical and spectroelectrochemical properties indicate that both solvents and anions have a large influence on the electronic structure. Also, the its induced chirality of $\mathrm{Zn}^{\mathrm{II}}$ porphyrin dimer upon addition of (1S,2S)-(+)- and (1R,2R)-(-)-1,2-diaminocyclohexane which produced a stable 1:1 tweezer complexes exhibited distinctive derivative-shaped band morphology of the pseudo-Faraday- $A_{1}$ terms on the MCD spectra, and the molecular polarization could be modulated by the chirality of guest chiral diamines.

Acknowledgements. Financial supports were provided by the National Scientific Foundation of China (Nos. 21171076, 21701058), Scientific Foundation of Jiangsu Province
(No. BK20160499) and the fund from the State Key Laboratory of Coordunation Chemistry (No SKLCC1710).

\section{References}

1. (a) Jiang H.W., Kim T., Tanaka T., Kim D., Osuka A. Chem. Euro. J. 2016, 22, 83-87; (b) Yoon M.C., Noh S.B., Tsuda A., Nakamura Y., Osuka A., Kim D. J. Am. Chem. Soc. 2007, 129, 10080-10081; (c) Drobizhev M., Stepanenko Y., Dzenis Y., Karotki A., Rebane A., Taylor P.N., Anderson H.L. J. Am. Chem. Soc. 2004, 126, 15352-15353; (d) Kim K.S., Lim J.M., Osuka A., Kim D. J. Photochem. Photobiol. C 2008, 9, 1328; (e) Souza F., Subbaiyan N.K., Xie Y., Hill J.P., Ariga K., Ohkubo K., Fukuzumi S. J. Am. Chem. Soc. 2009, 131, 1613816146; (f) Xie Y.S., Hill J.P., Schumacher A.L., Sandanayaka A.D., Araki Y., Karr P.A., Labuta J., Souza F., Ito O., Anson C.E., Powell A.K., Ariga K. J. Phys. Chem. C 2008, 112, 10559-10572.

2. (a) Tanaka T., Osuka A. Chem. Rev. 2017, 117, 2584-2640; (b) Crossley M.J., Burn P.L. J. Chem. Soc., Chem. Commun. 1987, 39-40; (c) Tsuda A., Osuka A. Science 2001, 291, 7983; (d) Ooi S., Tanaka T., Osuka A. Inorg. Chem. 2016, 55, 8920-8927.

3. (a) Lin V.S., DiMagno S.G., Therien M.J. Science 1994, 264, 1105-1111; (b) Arnold D.P., Nitschinsk L.J. Tetrahedron 1992, 48, 8781-8792; (c) Anderson H.L. Inorg. Chem. 1994, 33, 972-981; (d) Anderson H.L. Chem. Commun. 1999, 2323-2331.

4. Pawlicki M., Morisue M., Davis N., McLean D., Haley J.E., Beuerman E., Drobijev E., Rebane A., Thompson A.L., Pascu S.I., Accorsi G., Armaroli N. Anderson H.L. Chem. Sci. 2012, 3, 1541-1547.

5. (a) Naruta Y., Sasayama M., Sasaki T. Angew. Chem. Int. Ed. 1994, 33, 1839-1841; (b) Shimazaki Y., Nagano T., Takesue H., Ye B., Tani F., Naruta Y. Angew. Chem. Int. Ed. 2004, 43, 98100; (c) Groves J.T., Lee J., Marla S.S. J. Am. Chem. Soc. 1997, $119,6269-6273$.

6. Takai A., Gros C.P., Barb J.M., Guilard R., Fukuzumi S. Chem. Eur. J. 2009, 15, 3110-3122.

7. (a) de Jong J.J.D., Lucas L.N., Kellogg R.M., van Esch J.H., Feringa B.L. Science 2004, 304, 278-281; (b) Inouye M., Waki 
M., Abe H. J. Am. Chem. Soc. 2004, 126, 2022-2027; (c) Fasel R., Parschau M., Ernst K.H. Angew. Chem. Int. Ed. 2003, 42, 5178-5181; (d) Borovkov V.V., Fujii I., Muranaka A., Hembury G.A., Tanaka T., Ceulemans A., Kobayashi N., Inoue Y. Angew. Chem. Int. Ed. 2004, 43, 5481-5485.

8. (a) Xu L., Huang T.T., Liang X., Mack M., Harris J., Nyokong T., Li M.Z., Zhu W.H. J. Porphyrins Phthalocyanines 2016, 20, 647-655; (b) Borovkov V.V., Hembury G.A., Inoue Y. Acc. Chem. Res. 2004, 37, 449-459; (c) Guo Y.M., Oike H., Aida T. J. Am. Chem. Soc. 2004, 126, 716-717; (d) Balaban T.S., Bhise A.D., Fischer M., Linke-Schaetzel M., Roussel C., Vanthuyne N. Angew. Chem. Int. Ed. 2003, 42, 2140-2144.

9. (a) Liang X., Xu L., Li M.Z., Mack J., Stonec J., Nyokong T., Jiang Y., Kobayashi N.,Zhu W.H.J.Porphyrins Phthalocyanines 2015, 19, 819-829; (b) Li M.Z., Zhang Q., Xu L., Zhu W.H., Mack J., May A.K., Nyokong T., Kobayashi N., Liang X. ChemPlusChem 2017, 82, 598-606.
10. Gouterman M. In: The Porphyrins, Vol. III, Part A (Dolphin D., Ed.), New York: Academic Press, 1978. p. 1-165.

11. (a) Michl J. J. Am. Chem. Soc. 1978, 100, 6801-6811; (b) Michl J. Pure Appl. Chem. 1980, 52, 1549-1563; (c) Michl J. Tetrahedron 1984, 40, 3845-3934.

12. (a) Mack J., Stillman M.J., Kobayashi N. Coord. Chem. Rev. 2007, 251, 429-453; (b) Kobayashi N., Muranaka A., Mack J. Circular Dichroism and Magnetic Circular Dichroism Spectroscopy for Organic Chemists. Cambridge: Royal Society of Chemistry, 2011; (c) Piepho S.B., Schatz P.N. Group Theory in Spectroscopy with Applications to Magnetic Circular Dichroism. New York: John Wiley and Sons, 1983. (d) Stephens P.J. Adv. Chem. Phys. 1976, 35, 197.

13. (a) Veyrat M., Ramasseul R., Turowska-Tyrk I., Scheidt W.R., Autret M., Kadish K.M., Marchon J. Inorg. Chem. 1999, 38, 1772-1779; (b) Kadish K.M., Davis D.G. Ann. N.Y. Acad. Sci. 1973, 206, 495-503. 